\title{
DEMOCRATIC LEGITIMACY AS A CRITERION FOR THE RECOGNITION OF GOVERNMENTS: A RESPONSE TO PROFESSOR ERIKA DE WET
}

\author{
Obiora Chinedu Okafor*
}

In her thought-provoking contribution to this symposium on the contemporary status of democratic legitimacy as a criterion for the recognition of governments, Professor de Wet argues, ${ }^{1}$ in the main, that contrary to the great expectations of the 1990s that democratic legitimacy "was becoming an additional or even alternative criterion to effective control for the purpose of the recognition of governments," there is as yet no clear customary international law rule against the recognition of governments that come to power though non-democratic means. She arrives at this conclusion by examining the relevant state practice, almost all relating to the African continent. In her view, this state practice has been too inconsistent to support the emergence of the relevant customary international law rule and the displacement of the traditional international law position that it is the effectiveness of a government that confers legitimacy on it and warrants its recognition by other governments. Furthermore, Professor de Wet also accounts for at least some of the relevant treaty law, pointing to what she views as the inconsistent application of the relevant treaty provisions by the concerned states and international organizations.

Assessed strictly on its own (narrower) terms, Professor de Wet's major argument regarding the nonsolidification to date of a clear global-level customary international law rule against the recognition of undemocratically installed governments is more or less correct. Few would disagree that, at least on the global level, the relevant state practice does not appear to be consistent enough at this point to found custom. Overdetermined by power and ideational politics, state behavior in this area has tended to bob and weave, rise and fall, and dart around the map. For example, as Professor de Wet makes clear, viewed from the global perspective, the undemocratic ousting of a government from power has not been as good a predictor of the recognition practices of states as one might have expected. To this day, the more powerful global players often seem much more interested in installing and recognizing friendly regimes than in the democratic nature of a government's climb to power (as in Egypt and Ukraine). This was well-recognized even by many of those who had pointed out the emerging trend toward the use of the democratic legitimacy principle in recognition praxis. ${ }^{2}$ And so, Professor de Wet and I agree on the general thrust of the overarching argument that she proffers.

Nonetheless, some may take issue with aspects of the contents of Professor de Wet's comment, and I do so on two main grounds. The first is with regard to certain omissions in the argument: she does not address squarely and in sufficient detail certain important questions and issues that might shed significant light on the subject of her commentary. While it is recognized that space constraints may have limited the breadth of

* Professor at Osgoode Hall Law School, York University.

Originally published online 27 Jan. 2015.

${ }^{1}$ Erika de Wet, From Free Town to Cairo via Kiev: The Unpredictable Road of Democratic Legitimacy in Governmental Recognition, 108 AJIL UNBOUND 201 (2015).

2 See, e.g., Sean D. Murphy, Democratic Legitimacy and the Recognition of States and Governments, 48 INT'L \& ComP. L.Q. 545 (1999).

ASIL and Obiora Chinedu Okafor (C) 2015 
Professor de Wet's analysis, the failure to address these questions pushed to the background certain questions that, were they to have been foregrounded, would have provided a more complete and balanced picture of the state of the international law of governmental recognition. The second ground on which some may take issue with Professor de Wet's comment concerns several of her claims that are open to challenge.

\section{Silences}

\section{Who "Disappeared" International Treaty Law?}

The first of the silences in her commentary that might have significance for her overall argument is that Professor de Wet does not squarely interrogate international treaty law, focusing her analysis on the emergence or otherwise of a customary international law norm that prescribes democratic legitimacy as one of the criteria for recognition of governments. Even her illuminating consideration of the African regional treaties is focused on gleaning state practice in observing or violating these regional treaties-her aim in this respect being to assess whether or not the relevant custom has emerged. But customary international law is, obviously, not the only genre of international law available to be assessed in this regard. Thus, it is one thing to argue that a clear customary international law rule against the recognition of undemocratic governments has not yet emerged and another to contend that no international law rule of a similar character exists. The first argument may be correct while the second may be wrong, or both may be either right or wrong. And so, a consideration of the position under custom does not dispose of the question at hand in a completely satisfactory manner.

Professor de Wet, however, leaves the reader unclear as to what her position is regarding the existence on the global (as opposed to merely on the African) level of an implied, subsidiary rule of international treaty law prohibiting or discouraging the recognition of undemocratically installed governments. For example, how do the sundry global-level treaty provisions that require all peoples to have access to self-determination and political participation in their own governance, and so on (e.g., under Common Article 1 of the International Covenant on Civil and Political Rights ${ }^{3}$ (ICCPR) and the International Covenant on Economic, Social and Cultural Rights ${ }^{4}$ (ICESCR)) square with a rule of governmental recognition that treats the effective control of a society by a government as either the only criterion for recognition or the most important one? Were these international treaty provisions to be taken seriously and accounted for in the analysis of the state of the international law on the recognition of governments, would this lead us to the conclusion that recognition doctrine must be governed (at least to a larger degree than is suggested by an analysis of the relevant custom) by the principle of democratic legitimism? ${ }^{5}$ Would it imply the existence of a subsidiary, treaty-rooted norm in favor of the democratic legitimacy criterion in governmental recognition? Can we have one (a democratic entitlement) without the other (a rule of recognition that is at the very least strongly rooted in democratic legitimism)? How does the intersectionality of norms, a well-accepted aspect of international legal analysis, which was relied on in the Declaration on Friendly Relations, square here?6 Do international law norms not speak to each other? Are they confined to their silos? Assuming, for example, that the international treaty law

${ }^{3}$ International Covenant on Civil and Political Rights, GA Res. 2200A (XXI), U.N. Doc. A/6316 (1966) (entered into force Mar. 23, 1976).

4 International Covenant on Economic, Social and Cultural Rights, Dec. 16, 1966.

5 John Dugard, ReCognition And THE United NATIONS (1987); Obiora C. Okafor, The Global Process of Legitimation and the Legitimacy of Global Governance, 14 ARIZ. J. INT'L \& COMP. L. 117 (1997).

${ }^{6}$ See, e.g., the conceptual framework underpinning the discussion in Frederic L. Kirgis, Jr., Comment: The Degrees of Self-Determination in the United Nations Era, 88 AJIL 304 (1994). 
right to self-determination in Common Article 1 of the ICCPR and the ICESCR confers the democratic entitlement on at least the citizens of those states that have ratified one or both of the two covenants (which turns out to be most states in the world), how can it be that a government that results in those states from the exercise of that right can be lawfully denied recognition (even if it is not in effective control), and how can it be that a government that egregiously violates these rights can be lanfully accorded recognition under the prevalent international treaty law.

The emphasis here is on the word "lawfully" because when it comes to international treaty law (as opposed to customary international law), one cannot simply wave aside treaty law or its implications by pointing to inconsistent or contrary state practice. States may many a time violate or not observe the provisions of a treaty but that does not necessarily push the relevant treaty into desuetude. If this were the case, international treaty law as a category might have already ceased to exist altogether. After all, violations of treaties are as rife in international society as violations of the criminal law are in the domestic sphere. A gap must necessarily exist between norms and facts. ${ }^{7}$

One can, of course, disagree that there is even anything like a democratic entitlement under international law, but it seems to me that once one accepts that it does exist, then one must also accept that -at least at the level of legal text - that entitlement may have paradigmatic implications for international law on the recognition of governments. ${ }^{8}$

Similar questions may be raised in relation to other norms of international law that are widely recognized as already having the status of jus cogens (peremptory norms of general international law from which no derogation is permissible). Norms such as those prohibiting genocide and racial discrimination leap quickly to mind. Can the recognition behavior of states lawfully derogate from these norms (which, among other key human rights norms, complement the self-determination norm to constitute what many would see as the core of the democratic governance idea)? It would help to have Professor de Wet's views on these relevant and important questions.

\section{How Far is the International Law of Recognition from the "Promised Land"?}

Another issue that is left largely unaddressed in Professor de Wet's comment is the extent to which tolerance for coups and other undemocratic changes of government at the UN and African Union levels, and thus in state practice, has increased, remained the same, or waned since the "high water mark" of the 1990s. Conversely, to what extent has respect for democratic legitimacy as a criterion for governmental legitimacy and recognition increased, remained the same, or waned in intensity since then? While it is understood that Professor de Wet's concern is to answer the question whether or not customary international law now clearly prohibits the recognition of a government that has come to power in a non-democratic manner, these are important questions about trajectory and direction that might give the reader a better idea of the state of affairs in the area of international law on recognition. For instance, Prof de Wet argues that "states will continue to apply the democratic legitimacy criterion as one of various factors to consider when recognizing a government - the most important of these, however, still being effective control." Yet, without a broaderand therefore better - understanding of the extent to which the tide has or has not turned toward the use of the democratic legitimacy criterion, it is difficult for even those who accept this turn to get a sense of how remote the emergence of such custom is. Are we on the cusp of a paradigm shift, a transformation? Or are

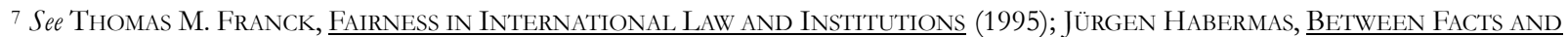
Norms: CONTRIBUtions TO A Discourse TheOrY OF LAW AND DEMOCrACY (William Rehg trans., 1996).

8 See Dugard supra note 5; Okafor supra note 5.
} 
we light years away from "the promised land" which J. E. S. Fawcett" dreamt of as far back as the 1960s. How far away are we from fully realizing what Karen Knop has referred to as "the righting of recognition"? 10 While this is not a huge concern with Professor de Wet's comment, it is an important one nonetheless. The African Union's handling ${ }^{11}$ of recent events in Burkina Faso underscores this point.

\section{Contentious Arguments and Claims}

\section{Re-reading the African Evidence}

As suggested earlier, there are certain aspects of Professor de Wet's analysis with which some may take issue. The first and most important of these is her analysis of the African evidence, on which her argument heavily relies. A careful reader of her analysis will, for the most part, find it difficult to agree with her. She notes quite correctly that Article 4(p) of the Constitutive Act of 2000 of the African Union condemns any unconstitutional (including undemocratic) change of government, but goes on to claim that the practice of that body in relation to the enforcement of Article 4(p) "has however not been consistent." But the evidence she supplies in favor of this key conclusion does not, in my view, support so strong a claim on her part. In fact, undercutting her own argument, she actually cites to the fact that the African Union has sanctioned or condemned virtually every unconstitutional or undemocratic change of government of government in Africa since 2003 (in a total of six cases). Her grounds for regarding this evidence as "inconsistent" are that, in two of those six cases, the African Union "merely" condemned the changes of government without imposing sanctions. With respect, the weight of evidence here is not sufficiently inconsistent to ground a claim that no regional custom has emerged in Africa. Does the emergence of custom require complete and total uniformity in state practice? In any case, as I read them, at best, these cases reveal marginal inconsistency. Indeed, all six cases are oriented, albeit in varying degrees of intensity, toward the requirement of democratic legitimacy as the chief criterion for governmental recognition. Condemnations, even without the imposition of sanctions, do not imply that the impugned changes of government were condoned in the two cited cases.

Similarly, Professor de Wet's treatment of the state practice with regard to the popular revolts that have occurred in Africa and the installing of unelected transitional regimes in some states on that continent leaves much room for disagreement. Her argument that the African Union's recognition of transitional regimes that are meant to bring peace to a country, accommodate all sides to the tensions and conflicts at issue, andcrucially—transit the country to democracy (e.g., in Libya, Mali, and now Burkina Faso) is evidence of inconsistent state practice in this area is not convincing. It is difficult to see how this evidence detracts significantly from the application of the criterion of democratic legitimacy in governmental recognition. For example, in the Libyan case, it is not as if the transitional government installed in that country had overthrown a democratic regime. Quite to the contrary, it claimed to have seized power in order to attempt to restore democracy. How does this detract from the utilization of the democratic legitimacy principle in the recognition of governments in Africa? A similar argument can be made in respect of the Mali and Burkina Faso cases, where the army was pressured away from seizing power for any longer than the short transitional period precisely in defence of the principle of the non-recognition of non-democratic governments that is based on AU treaty law and taking root in that organization's practice. As such, while Professor de Wet is, as I have suggested, correct to argue that no global-level customary international law norm has as yet emerged requiring the non-

9 J. E. S. Fawcett, The Law of Nations, 27 CAMBridGE L.J. 134 (1969).

${ }^{10}$ Karen Knop, The Righting of Recognition: Recognition of States in Eastern Europe and the Soviet Union, in SELECTED PAPERS IN INTERNATiOnAL LaW: Contribution Of THE CANAdian COUNCIL ON INTERNATIONAL LAW 261 (Yves Le Bouthillier et al. eds., 1999).

${ }^{11}$ Burkina Faso Declares Michel Kafando Interim resident, BBC News (Nov. 17, 2014). 
recognition of all governments that came to power through undemocratic means, it is not as clear that she is as correct with respect to the regional African context.

The second claim that is made in the comment with which some may take issue is that, as unconstitutional as the act was, "the ouster of the Yanukovych government [in Ukraine] . . was not, as such, a violation of international law, nor was the recognition of its successor government." While, as I have argued, Professor de Wet is correct that there is no global-level customary (as opposed to treaty) international law norm that requires the non-recognition of undemocratically installed governments, it is much more doubtful than she has acknowledged that there is no such treaty-rooted, subsidiary, and implied, non-recognition norm-one that flows, inter alia, from the democratic entitlement, self-determination, anti-genocide, and anti-racial discrimination norms. What is more, the claim that the ouster of Yanukovych in itself was not a violation of international law is, in my view, of doubtful validity. This is a separate question from that of the legality of the recognition of the successor government. And the two questions ought not to be conflated. In any case, there is significant evidence that - at least in treaty international law - the ouster of a democratically elected regime may now be widely regarded as unlawful in international law. ${ }^{12}$ While this does not, of course, necessarily mean that the democratic entitlement has fully emerged into international law, it should require a more tentative analysis of the question of the legality or otherwise of the forcible or unconstitutional ouster of Yanukovych and others like him.

Thus, in the end, I certainly do have significant challenges to some aspects of Professor de Wet's comment. However, this does not detract from the fact that I find myself in agreement with her main argument (concerning the current state of the global customary-as opposed to treaty-international law on the recognition of governments).

12 Thomas M. Franck, The Emerging Right to Democratic Governance, 86 AJIL 46 (1992); Rüdiger Wolfrum, International Economic Law: in The Max Planck Encyclopedia of Public International Law (F. Lachenmann ed., 2015); Obiora C. Okafor, The Concept of Legitimate Governance in the Contemporary International Legal System, 44 NETH. INT’L L. Rev. 33 (1997). 